\title{
FORTUNA VS. ESTATUS: \\ LA MOVILIDAD SOCIAL \\ EN EL MÉXICO DECIMONÓNICO
}

\author{
Anne Staples* \\ El Colegio de México
}

U

n precepto aprendido por los niños, desde tiempos de la conquista, fue la aceptación del orden social ya establecido. Dios había creado a ricos y pobres, reyes y súbditos y a la familia, donde la figura del padre reunía en sí la esencia misma de la jerarquía. Había que entender que cada quien tenía su lugar y un papel que desempeñar. ${ }^{1}$ La idea de "progresar", de subir o bajar en la escala social, de dejar de ser quien se era para convertirse en otra persona del nivel que fuera, no concordaba con la perfecta sociedad católica de estamentos bien delineados, conformes con la suerte y comprometidos a mantenerse tal cual, en bien de la estabilidad. Varios refranes populares subrayan este precepto. Uno que

Fecha de recepción: 16 de enero de 2015

Fecha de aceptación: 21 de julio de 2015

* Agradezco a Maddelyne Uribe su ayuda en la preparación de este artículo.

${ }^{1}$ Staples, "El temor a Dios y el temor al Estado", pp. 461-480. 
viene al caso para el siglo XIX dice: "El que nació para pobre aunque sea un Salomón”, por el que se supone que ni los estudios ni el talento borraban la condición originaria del individuo. El refrán, y la creencia popular que se encuentra en su origen, afirman "como principio indiscutible una predestinación según la cual cada quien nace con el destino que nadie puede cambiar, haga lo que haga". ${ }^{2}$ Estos dichos inciden en el meollo del tema: que se puede aumentar la riqueza o adquirir profundos conocimientos sin cambiar de estatus, del lugar dentro de la sociedad en el cual nace uno. Y el reverso es cierto también: una pérdida de fortuna no significa, necesariamente, resbalar en la escala social ni en la estima de los contemporáneos. Este fenómeno es válido para toda la historia de México, salvo casos especiales, y tal vez más en el presente, pero justifica considerarlo para toda la extensión del siglo XIX.

En 2003 la historiadora Brígida von Mentz coordinó un libro sobre la movilidad social en México, en el cual varios capítulos versan sobre temas del siglo XIX. Las preguntas que se hicieron los autores son las mismas que los estudiosos se hacen actualmente: "cómo crecen o decaen ciertos negocios, cómo cambian de estatus social algunas personas al correr el tiempo y cómo estas experiencias arrojan luz sobre las transformaciones regionales o sobre la coyuntura general; también, cómo los destinos están ligados a ciertos azares de la vida familiar o cuáles son las consecuencias de decisiones personales". ${ }^{3}$ Se pueden agregar a estas inquietudes otras preguntas: ¿Qué factores influyeron en el destino

2 Pérez Martínez, Refranero mexicano, p. 19.

3 Mentz, Movilidad, p. 7. 
de los hombres nacidos en el seno de una familia sin recursos, participaran o no de la cultura criolla citadina? ¿Cómo forjaron sus fortunas o sus éxitos? Forzosamente hay que considerar, a la hora de buscar respuestas a estas preguntas, otra observación de B. von Mentz, de que "la movilidad social es siempre relativa, pues depende de la sociedad circundante y está relacionada con las leyes, costumbres y valores vigentes en determinada época y lugar". ${ }^{4}$ Desde luego que no es lo mismo llegar hasta la cumbre de la sociedad mexicana del siglo xIx que hacerlo en Inglaterra, por ejemplo, pues las elites inglesas necesitaban más que dinero para ostentarse como tales, ya que se privilegiaba el origen familiar sobre la cuenta bancaria. Es claro que la fortuna y el estatus no fueron sinónimos.

El propósito de este artículo es ver de qué manera los individuos, incluyendo una que otra mujer, modificaron su espacio social durante el turbulento siglo xIx y qué significó para ellos. Algunos se enriquecieron y otros se empobrecieron. ¿Para quiénes eran aceptables estos cambios que a veces los alejaban de su entorno nativo? La metodología será la de agrupar las causas, los procesos o los acontecimientos que favorecieron el cambio de estatus, en sentido positivo o negativo, para entender con mayor amplitud lo flexible de las formas sociales. Ningún país puede considerarse estático y México menos, pues se encontraba en pleno proceso de conformación, como Estado, como nación, como patria y como sociedad (o más bien, un mosaico de sociedades, con enormes diferencias geográficas, raciales, lingüísticas y económicas). La inestabilidad política y financiera contribuyó a

${ }^{4}$ Mentz, Movilidad, p. 7. 
hacer de México un laboratorio en el cual pueden examinarse la causa y el efecto de la movilidad social, la modificación de formas de convivencia, la integración de nuevos grupos y la desarticulación de estratos vinculados al Antiguo Régimen.

El siglo XIx fue el de carreras nuevas, como el periodismo y la abogacía, dos caminos que facilitaron el paso a puestos políticos, al manejo de contratos y a vivir de los fondos públicos, que representaron una novedad respecto de las costumbres virreinales, no sólo profesionalmente sino en cuanto a la movilidad social. Se amplió el número de periódicos y su circulación, siendo éste un fenómeno común al siglo, y en consecuencia el número de escritores para llenar sus páginas. Los abogados encontraron fuentes de trabajo multiplicadas por el número de estados de la República, ya que cada uno necesitaba un corpus de legislación nueva. Había que redactar nuevas constituciones, leyes y decretos, reglamentos, circulares, sentencias judiciales, y presidir los tribunales que surgieron en las capitales de los estados o departamentos. Los abogados entendían de la aplicación de la ley, así que se requerían en los despachos de hacienda y en los demás ministerios de gobierno. Los nuevos institutos literarios de ciencias y artes, los seminarios diocesanos tridentinos y las dos universidades, que funcionaban a ratos, producían "camadas" de abogados, en respuesta a la demanda de la carrera más popular del siglo xIx. Estas instituciones no cobraban colegiaturas a los externos, de modo que los muchachos sin recursos podían matricularse sin costo. Presentar los exámenes, sin embargo, sí exigía el pago de cuotas que sólo la presencia de un rico padrino podía solventar. Pero dentro de las profesiones, sin duda la abogacía fue la que proporcionó mayores ingresos y estatus social. 
Las ciencias demandaron una formación alejada de la humanística tradicional, y en ellas el origen social del individuo contaba mucho menos que su inteligencia. Los ingenieros, tanto mineros como militares, empezaban a salir al mercado de trabajo después de realizar estudios en el Seminario de Minería y el recién fundado Colegio Militar. El ejército, y en menor medida las milicias, dieron entrada, a veces por la fuerza de la leva, a jóvenes sin porvenir que terminaron ejerciendo el dominio de las armas contra sus enemigos, casi siempre políticos opositores. Se volvió costumbre, en ese siglo de pronunciamientos sin fin (se calcula que hubo unos 1500$),{ }^{5}$ otorgar promociones de grado a todos los vencedores en una contienda, aunque no se hubiera disparado un solo tiro. Para el siglo XIx en México, el ejercicio del poder militar y posteriormente del político por parte del mismo individuo fue un fenómeno común. Todos los presidentes salvo Benito Juárez y Lerdo de Tejada fueron militares. Político y militar llegaron a ser casi términos sinónimos, por estar el gobierno nacional y el de los estados en buena parte en manos de militares, así que el encumbramiento de los dos grupos seguía procesos similares.

Estos personajes se daban a conocer mediante la prensa debido a algún caso sonado o por batallas ganadas (victorias inventadas o no), por el desempeño de puestos de liderazgo, por brillar como oradores y por encontrarse en el lugar adecuado en el momento preciso. Acercarse a un buen padrino, poseer un talento natural, saber portarse en sociedad y tener una apariencia física atractiva (que fue, sobre todo, el caso de los militares con sus uniformes vistosos)

${ }^{5}$ Fowler, Malcontents, p. x. 
ayudaba a brincar las barreras de un pobre nacimiento. Sin duda la carrera militar gozó de un prestigio igual al que tuvo durante el virreinato: con frecuencia las familias distinguidas dedicaban un hijo al ejercicio de las armas, como cadete en el Colegio Militar. La multiplicación de carreras en el siglo XIX diseminó su influencia; las armas ya no eran la única opción para un hijo segundón. Habría que recordar que el ejército era y es una organización jerárquica. No era lo mismo ser soldado raso que oficial. Sin embargo se dieron casos de ascensos espectaculares, en los cuales un oficial de menor rango se convertía en general en poco tiempo. Tampoco funcionaban las mismas reglas para el ejército regular que para las milicias estatales; en éstas, todo tipo de influencias, desde el dinero hasta las relaciones familiares, determinaban los grados y las prerrogativas de los militares que vivían en sus localidades, dedicados a las actividades cotidianas, inmersos en la estructura de la sociedad local que excluía, casi por definición, cualquier movilidad social.

No desaparecieron, de ninguna manera, las vías de acceso al poder eclesiástico para muchachos pobres o huérfanos, que puestos bajo la tutela de un tío párroco, por ejemplo, para sus primeras clases de latín, cursaban después el plan de estudios completo en alguno de los nueve seminarios diocesanos conciliares que se ubicaban en el México decimonónico.

Otro grupo cuyo ascenso cambió la historia de Europa desde la Edad Media y sobre todo desde la revolución industrial fue el de los comerciantes. En México los negocios, tanto de compra venta de mercancías como de inversiones en minas o haciendas, por sólo nombrar algunos, fueron un camino al éxito y, en una o dos generaciones, facilitaron el ingreso a los grupos más envidiados de la sociedad. Los nuevos ricos no 
sufrieron mucho tiempo el desprecio del dinero viejo hacia ellos, pues pronto llegaron otros enriquecidos todavía más recientes. Los comerciantes fueron los más numerosos de entre los individuos tenidos por "superiores" por la opinión pública debido a la ostentación con que vivían. Éste fue el grupo que más fácilmente disfrutó para sí o rechazó para los demás la movilidad social.

La mayoría de la población siguió la vida de siempre, en poblados de menos de 500 habitantes, aislados, lejos de buenas vías de comunicación, dedicados a las labores tradicionales del campo, de la ranchería, de la pequeña villa. La población indígena, monolingüe, no concebía siquiera un concepto tan extraño como la movilidad social. Así que no fue un fenómeno común. Lo descrito aquí son casos aislados y lo único que muestran es que no fue imposible de lograr.

EL CAMINO ASCENDENTE GRACIAS A LA ESCUELA

¿Cómo salir de pobre, del mísero lugar, apartado y malsano, que le vio a uno nacer? ¿ $\mathrm{O}$ de un ambiente urbano, igual de agresivo, de una familia de recursos medianos pero sin mayores perspectivas de triunfo en la vida? Un elemento común a muchos políticos, militares, comerciantes e intelectuales del siglo XIx, de cuna humilde o desconocida, fue aprovechar las oportunidades educativas que ofrecieron los establecimientos escolares, tanto tradicionales como de nueva creación. Se puede explicar el ascenso de Benito Juárez, en parte, por el apoyo que tuvo para asistir al Seminario Conciliar de Oaxaca y al Instituto Literario de esa misma entidad. Porfirio Díaz, años después, siguió el mismo camino. Ambas instituciones o sus similares en otros 
estados ofrecieron los conocimientos indispensables para ingresar a la profesión más importante del México independiente: la abogacía. Ya sin requisitos de sangre y gracias a las becas municipales, a las becas nacionales de San Ildefonso o a las del Colegio de Minería, por nombrar sólo algunas, los muchachos con capacidad de aprendizaje libresco pudieron matricularse. Otros consiguieron, como durante el virreinato, puestos de bibliotecario o de sirviente dentro de los colegios. Ignacio Comonfort sirvió de criado en el Colegio del Espíritu Santo en Puebla. A veces el joven no podía presentar los exámenes debido a las exigencias de algún compañero privilegiado, que le pedía un servicio justamente en el horario escolar, como si fuera un intento por obstaculizar su carrera. Comonfort no pudo terminar sus estudios pero sacó provecho de lo que aprendió. Melchor Ocampo, hacendado y dueño de una fina educación, lo consideraba “escaso de instrucción y remiso de carácter”, tal vez más por rivalidades políticas que por la clase social. ${ }^{6}$ Comonfort es un buen ejemplo de cómo los vientos de la fortuna soplaban en un sentido y luego en otro. Provenía de "una distinguida familia criolla, venida a menos económicamente”. Después de sus humillaciones en el Colegio de Puebla, se hizo "rico comerciante, con valiosas propiedades en el departamento de Guerrero". Fue comandante militar de Tlapa, ${ }^{7}$ entre otros cargos. Enrique Krauze agrega a esta información el hecho de que había heredado una hacienda en su estado natal y comprado otra en Tlalnepantla. ${ }^{8}$ De

\footnotetext{
6 VALAdÉs, Obras, p. 213.

7 Díaz Díaz, Candillos y caciques, p. 260.

8 Krauze, Siglo de caudillos, p. 221.
} 
rico pasó a pobre y, más tarde, de nuevo volvió a disfrutar de los bienes materiales.

Igualmente famosos, como los casos de Juárez y Porfirio Díaz, son los de Ignacio Ramírez e Ignacio Manuel Altamirano. Interesa agrupar a estos cuatro individuos por ser indígenas o mestizos, tres del sur y uno del centro del país. De los cuatro, en un principio Ramírez fue el más afortunado, al nacer en San Miguel el Grande, ahora de Allende, de un padre vicegobernador de Querétaro, de ideas políticas avanzadas, apoyo de las reformas de Valentín Gómez Farías y comprometido con el combate al clero y a los privilegios. Envió a su vástago al Colegio de San Gregorio en la ciudad de México, antiguamente dedicado a la educación indígena, regenteado por un amigo suyo, el famoso Juan Rodríguez Puebla. Ignacio aprovechó la biblioteca del Colegio y la de la catedral para adquirir una cultura libresca que fue la envidia de sus colegas y la admiración de sus alumnos a lo largo de su vida. De esta época es su sobrenombre del Voltaire de México. El escritor Hilarión Frías y Soto recordaba cómo "El traje del joven revelaba su pobreza, y sus maneras el encogimiento típico del colegial". 9 Su larga carrera como escritor, abogado, catedrático, naturalista, político y ministro de Estado habla de un talento natural sobresaliente, una voluntad férrea, una disciplina para el estudio y para el trabajo que lo elevó en la escala social hasta pertenecer a la aristocracia del saber en el México decimonónico. Despreciaba la riqueza y los honores, su encumbramiento no le pareció indebido ni inmerecido, sino connatural a la lucha que llevó toda su vida por mejorar la educación y la libertad política.

9 Altamirano, Obras completas, vol. xiII, pp. 104, 107-109, 111. 
Para sobrevivir, después de su renuncia al gabinete de Juárez, se trasladó a Puebla para desempeñar las cátedras de Derecho Romano y de Literatura, "pobre, pobrísimo" como dice otro biógrafo suyo, Ignacio Manuel Altamirano. Antes de morir, "las pocas cosas de valor que poseía la familia se habían sacrificado, y no quedaba nada". ${ }^{10}$ Se tuvo que avisar al presidente Díaz para solicitar fondos con los cuales enterrarle. Su movilidad fue intelectual y política más que social y de ninguna manera económica. Sobresalió el Nigromante, su apodo literario, a pesar de los prejuicios raciales y sociales que intentaban restringir los honores y la fama a los bien nacidos, descendientes de europeos, imbuidos de valores religiosos y respetuosos de las categorías sociales de antaño.

Uno de los ejemplos más clásicos del papel que desempeñó la educación en la movilidad social es el de Ignacio Manuel Altamirano. Además de una inteligencia natural, el valor fue otro de los ingredientes imprescindibles para salir adelante. Altamirano no dejó constancia del miedo que seguramente sintió en 1849 al dejar la casa materna en Tixtla, para marcharse como becario al Instituto Literario de Toluca. Más bien, según él, reconoció la importancia del decreto impuesto a los ayuntamientos del Estado de México exigiendo a cada uno enviar y pagar los gastos de un muchacho indígena para que recibiera educación superior en Toluca. Podría uno pensar que lo que Altamirano escribió 30 años después fue más bien una reflexión matizada ya de adulto acerca de sus logros y no el sentimiento espontáneo al momento de los hechos:

10 Altamirano, Obras completas, vol. xiII, pp. 136, 145. 
Yo comprendí claramente que aquel cambio en mi vida era un gran bien para mí... Aquella ley [de designar becarios y enviarlos a Toluca] no sólo me favorecía a mí sino también a otros muchos jóvenes indígenas [unos 41] del Estado de México, pobrísimos como yo, y como yo condenados seguramente, si tal disposición no hubiera venido a salvarlos, a arrastrar una vida de ignorancia y de miseria. ${ }^{11}$

Décadas después, contó en entrevistas periodísticas las peripecias para llegar al colegio: llevaba cargando "el pobre bastimento de su mejor ropa, los zapatos amarrados al pescuezo para no gastarlos antes de tiempo y el modesto itacate de pinole y totopos”. Acompañado por su padre, tardó una semana en caminar a pie de Tixtla a Toluca, desde la tierra caliente, rumbo al Pacífico, a la gélida capital del Estado de México, la ciudad más alta y fría de la República. Tan sólo sobrevivir al cambio de clima y de alimentación ya era una proeza. $^{12}$

Llegar a Toluca no significó una mejoría en las condiciones de vida de Altamirano. "Con decir que éramos 'dos alumnos de municipalidad' está expresado todo lo que significa miseria, desahogo, flacura, rústica timidez y fealdad caricaturesca”. ${ }^{13}$ Además, la separación del terruño y del afecto materno:

11 Altamirano, Obras completas, vol. xiII, p. 105; también citado en Girón, Ignacio Manuel Altamirano en Toluca, p. 48.

12 Girón, Ignacio Manuel Altamirano en Toluca, p. 57.

13 Altamirano, Obras completas, vol. v, p. 335; también citado (p. 337) en Girón, Ignacio Manuel Altamirano en Toluca, p. 62. 
¿No lloras tú también ¡oh madre mía! al recordarme, al recordar el día en que te dije adiós, cuando en tus brazos sollozaba infeliz al separarme, y con el seno herido, hecho pedazos, aún balbucí tu nombre, al alejarme ${ }^{14}$

Comienzos duros, solitarios y tristes para un niño de 14 años de edad que superó el trauma de dejar su tierra y su familia, los prejuicios acerca de su calidad de indígena y la persecución debido a sus ideas liberales, hasta convertirse en político, diplomático y uno de los grandes autores costumbristas de las letras nacionales.

La educación salvó a más de uno de las consecuencias funestas de desgracias personales, como la muerte del padre y la consecuente orfandad. Pertenecer al mundo de las letras, por muy vacío que estuviera el bolsillo, daba entrada a la meritocracia y a la posibilidad de escalar posiciones dentro del gobierno. Guillermo Prieto, poeta, periodista, político y secretario de Hacienda del 14 de septiembre de 1852 al 5 de enero de 1853, es uno de los personajes que vivió los vaivenes de la fortuna. Nacido en el seno de una familia acomodada, la repentina muerte del padre y la inmediata locura de la madre dejaron a Prieto a la deriva. El adolescente tuvo que ver por sí y cuidar de la madre, lo que logró con una combinación de talento natural, buena suerte y mejor pluma.

En la infancia de Prieto, una sustanciosa herencia había permitido a la familia cambiar de estilo de vida. "La muerte

14 Altamirano, Obras completas, vol. vi, p. 64; también citado en Girón, Ignacio Manuel Altamirano en Toluca, pp. 70-71. 
de mi abuelo, acreciendo nuestra fortuna, nos hizo trasladar a México, en donde en menos que canta un gallo adquirí nuevas relaciones y se abrieron a mis ojos horizontes espléndidos". ${ }^{15}$ La muerte de su joven padre cambió de nuevo el rumbo de su vida. 16 "De los cuantiosos bienes de mi casa se apoderaron personas extrañas [...] sin amparo alguno, me refugié en la casa de unas señoras hijas de un dependiente de mi casa y que vivían honrada y pobremente de sus costuras". ${ }^{17}$ De allí a pequeños trabajos, un puesto en la Tesorería, el periodismo y finalmente la política, Prieto logró un lugar, igual que Altamirano, entre las figuras consagradas del siglo XIX mexicano. A fuerza de trabajo, tesón y aguante, y gracias a la educación recibida en el aula o adquirida por sí mismo, salió adelante. No fueron los centavos la llave de su éxito sino el prestigio de las letras y, sin duda, cierta notoriedad que le dieron a Prieto un renombre y un aprecio que significó su aceptación en los altos círculos intelectuales del país.

El lejano norte de la República da otro ejemplo de un muchacho nacido en cuna humilde, de padre ausente, de madre alejada de su tierra debido a la guerra de Reforma. Cuando por fin la familia se reunió en Colima, el padre zapatero pudo dar de comer a los suyos pero no sobraban recursos. La casa donde creció Gregorio Torres Quintero se componía de "unos cuantos cuartos con techo inclinado de teja, sobre grandes vigas, sostenidas por troncos de palmas clavados en el suelo y de paredes gruesas de adobe, como eran las casas de los humildes en ese tiempo". ${ }^{18} \mathrm{El}$

${ }^{15}$ Prieto, Memorias de mis tiempos, p. 29.

16 Prieto, Memorias de mis tiempos, p. 37.

17 Prieto, Memorias de mis tiempos, p. 38.

18 Rodríguez Álvarez, Yo, Gregorio Torres Quintero, p. 48. 
futuro pedagogo recordaba que "casi no pasábamos tiempo en el interior, que era muy modesto. Apenas tenía unos cuantos muebles de bejuco. Ahí sólo hacíamos las comidas y por la noche dormíamos en nuestros tapeixtle que tenían un petate como colchón. Estos últimos teníamos que enrollarlos muy temprano al levantarnos". Se bañaban en el río o en los baños públicos, ya que no había baño en la casa. Ésta tampoco tenía huerta ni corral de animales. Sólo un lavadero y un pequeño espacio para que jugaran los niños. ${ }^{19}$ Los domingos, Torres Quintero, junto con su hermano, vendía cerillos en el mercado o cargaba las bolsas del mandado a las señoras que acudían a comprar. Y seguramente ayudaba a su padre en la zapatería. ${ }^{20}$

Sin duda el factor "suerte" interviene en el destino de los que sobresalen y que se sobreponen al medio en el cual nacen. Al pequeño Gregorio le tocaron unos padres que por lo menos no ponían obstáculos en el camino. Pudo estudiar con un muy buen maestro de primaria, asistir al Liceo para Varones durante los pocos años que funcionó y ser seleccionado como uno de los alumnos que serían becados a la nueva Normal para Maestros en la ciudad de México. Tuvo la fortaleza, tal como su maestro Ignacio Manuel Altamirano, de dejar el terruño, el cariño de la familia, el amor de la novia y lanzarse, a caballo, diligencia y tren, a la fría y muy lejana ciudad de México, donde supo instalarse en una vecindad acorde con sus posibilidades económicas y sacar un enorme provecho de los estudios y de las relaciones sociales y profesionales con sus maestros y compañeros. Regresó a Colima

${ }_{19}$ Rodríguez Álvarez, Yo, Gregorio Torres Quintero, p. 48.

20 Rodríguez Álvarez, Yo, Gregorio Torres Quintero, p. 59. 
ya convertido en un profesional de la educación, comprometido con su vocación, que tomó muy en serio. Nuevamente la suerte le favoreció. La novia no se había ido con otro y después de esperarlo diez años, por fin se casaron (no todo sale bien en esta vida, ya que no tuvieron hijos). Torres Quintero escaló puestos dentro de la burocracia nacional, a principios del siglo xx, como jefe de Educación Pública en Yucatán, director de la Normal Mixta de Toluca y consejero técnico de la Educación Primaria y Normal bajo José Vasconcelos. Fue conferencista muy solicitado pero sobre todo escritor, y su fama, hasta la fecha, reside en sus libros de texto y en su método onomatopéyico para leer y escribir. Viajó un par de veces a Estados Unidos, se sacó la lotería (literalmente) y pudo comprar su propia casa en la ciudad de México, una verdadera rareza para un maestro de aquel entonces. Se jubiló con una buena pensión y dedicó un año y medio a viajar por Europa con bastantes comodidades. ${ }^{21}$ Llevó una vida cuyo destino cambió gracias a la educación, pero en primer lugar por la suerte, que le permitió acceder a la oportunidad de trascender su cuna humilde y acercarse a los centros del poder. El factor suerte no es ajeno al esfuerzo personal, ni a la pertenencia a redes sociales favorables a la colocación y promoción profesionales. No obstante, la constancia, el talento y otras prendas personales no han logrado impulsar a todo el mundo a superar la falta de oportunidades. En un país pobre y desorganizado, como lo fue México en el siglo xIx, muchos hombres de bien y de provecho quedaron varados en el camino.

${ }^{21}$ Rodríguez Álvarez, Yo, Gregorio Torres Quintero. 
La carrera de las armas poco tuvo que ver con las letras. Llegó un momento en el siglo xIx en que se prohibió a los oficiales decidir casos llevados a una corte marcial si no sabían leer y escribir, pues había analfabetos entre los militares de alto rango. Los atributos de un buen soldado fueron el valor, la resistencia física, la experiencia, el don de mando, la suerte para sobrevivir, pero no el conocimiento de las letras. El ejército fue el destino de hijos del pueblo sin tierras ni recursos, de los infortunados atrapados por la leva que los secuestraba de sus pueblos y rancherías, de muchachos con pocas ganas de estudiar pero con amor a la aventura, y de los hijos de antiguos militares o nobles con afición a una vida nómada condecorada con el honor o con una tumba. Éstos ingresaban a la Escuela Militar, hacían la carrera desde cadetes y pasaban directamente a ser oficiales. Otra categoría lo constituyeron antiguos combatientes de la guerra de independencia o caudillos locales, cuyo poder derivaba de su dominio del uso de la violencia. Los muchos pronunciamientos, todos con un elemento militar, fueron tierra fértil para la creación de un gran número de militares, pertenecientes al ejército o a alguna de las milicias estatales que a veces disputaban el poder. Los militares del siglo xIx mexicano tuvieron orígenes sociales y raciales poco homogéneos, pero todos los que alcanzaron los grados más altos vivieron historias de movilidad social. Al seguir una línea cronológica, se puede mencionar en primer lugar a Antonio López de Santa Anna. El padre era criollo, nacido en Veracruz en 1761, egresado de la Real y Pontificia Universidad de México, abogado de la Real Audiencia, 
subdelegado de Intendencia y ligado a los intereses comerciales y políticos del puerto. Su más reciente biógrafo, Will Fowler, subraya el desajuste entre su origen y la posición social de la familia que enfrentó el joven Antonio cuando encabezó el ejército:

Como soldado de la clase media de Veracruz, Santa Anna también sentiría que la ciudad de México, con su clase política tan “pretenciosa” como arrogante, era intimidante y hostil. En una sociedad en la que las distinciones sociales y de raza eran tan prominentes, es imposible dejar de observar las tensiones que debieron ser más que ostensibles entre Santa Anna, hijo provinciano de un burócrata de segunda clase, y los "seudoaristócratas” de la ciudad de México que transitaban por los pasillos de Palacio Nacional.

Fowler propone una respuesta novedosa a la vieja pregunta de por qué Santa Anna se retiraba con tanta frecuencia a su hacienda del puerto o al Encero, cerca de Xalapa, cuando estaba en la presidencia. "Los antecedentes de la clase media provinciana de Santa Anna explican en parte su disgusto hacia la capital y su propensión a salir de la ciudad de México siempre que tuvo la oportunidad". ${ }^{22} \mathrm{Si}$ el caudillo logró una movilidad social, en el sentido de ampliar sus relaciones y codearse con los grupos más poderosos económicamente hablando de la sociedad, no se sintió a gusto con su nuevo estatus. Prefirió la vida en sus haciendas, en las peleas de gallos, entre la tropa. Siempre fue un hombre más rural que citadino, más cercano a sus orígenes que a los ritos cortesanos de palacio. Además, en su tierra natal

${ }^{22}$ Fowler, Santa Anna, pp. 44, 49-50. 
disfrutaba del prestigio de hacendado y militar y allí podía atender personalmente sus negocios, que incluían la producción y venta de los productos de la tierra entre Xalapa y el puerto de Veracruz.

Vicente Guerrero, nacido igual que Altamirano en Tixtla, más tarde estado de Guerrero, fue quien sufrió un rechazo mayor por sus orígenes. A pesar de haber facilitado la independencia de México como militar y haber encabezado el ramo ejecutivo del gobierno federal, no se aceptaba al frente del gobierno a un hablante de náhuatl, que además se clasificaba como casta. ${ }^{23}$ La familia de Guerrero fue de prósperos arrieros ${ }^{24}$ pero esa ventaja económica no le ayudó cuando, como presidente de la República, fue acusado de incapacidad moral para desempeñar el puesto, por razón de su color (era mulato) -no la razón oficial, desde luego-- Pero el ser mulato no podía perdonarse en los círculos criollos de la ciudad de México. El ascenso social era imposible en este caso, mientras que el ser indígena no llevaba el mismo estigma. Habrá que recordar que la Constitución Política de la Monarquía Española de 1812 admitía sin mayores trámites a la ciudadanía a todos los habitantes (hombres mayores de 18 años) del imperio, siempre y cuando no tuvieran una gota de sangre africana. ${ }^{25}$ Guerrero no tuvo mucha escuela ni

${ }^{23}$ Morelos le pidió a Guerrero informarles en su idioma a 300 prisioneros indígenas que habían quedado libres. HuERTA-Nava, El guerrero del alba, p. 41.

${ }^{24}$ Huerta-Nava, El guerrero del alba, p. 14.

${ }^{25}$ La Constitución condicionó la ciudadanía a los descendientes de africanos en estos términos: artículo 22, "A los españoles que por cualquiera línea son habidos y reputados por originarios del África, les queda abierta la puerta de la virtud y del merecimiento para ser ciudadanos: en su consecuencia las Cortes concederán carta de ciudadano a los que hicieren 
modales finos, pero lo que le imposibilitó el ascenso social, a pesar de sus triunfos militares, fue el origen racial de sus padres, manchados, según la creencia de la época, de la inferioridad innata de un pueblo destinado a la esclavitud.

Anastasio Bustamante no tenía mayores perspectivas en la vida. Llegó al mundo en un hogar donde el padre se ganaba la vida vendiendo hielo, que transportaba a lomo de mula del volcán de Colima hasta la ciudad de Guadalajara. Como observa su biógrafa, Catherine Andrews, "Por nacimiento, pertenecía al estrato bajo de la sociedad criolla, y aspiraba a un futuro limitado" o por lo menos, esto es lo que le esperaba. ${ }^{26}$ La guerra de independencia le dio la oportunidad de entrar al ejército en un momento en que la escasez de oficiales era aguda y las posibilidades de ascenso, abundantes. Esta feliz coyuntura le permitió a Bustamente subir como la espuma, de teniente a coronel en menos de ocho años. ${ }^{27} \mathrm{La}$ presidencia del país no estaba lejos.

Otro militar que, como Santa Anna, tampoco quiso cambiar su estilo de vida, ni disfrutar de los beneficios de una movilidad social que le hubiera permitido convivir con hombres de bien, nacidos con pañales de seda, sentirse digno de la admiración o del reconocimiento del próximo o despertar su envidia, fue el caudillo Juan A. Álvarez. Venir

servicios calificados a la Patria, o a los que se distingan por su talento, aplicación o conducta, con la condición de que sean hijos de legítimo matrimonio de padres ingenuos; de que estén casados con mujer ingenua, y avecinados en los dominios de las Españas, y de que ejerzan alguna profesión, oficio o industria útil con un capital propio". O sea, que esta parte de la población debía haber ascendido ya en la escala social antes de poderse considerar merecedor de la ciudadanía.

26 ANDREws, Entre la espada y la Constitución, p. 19.

27 Andrews, Entre la espada y la Constitución, p. 20. 
de la costa del sur. Lejos de los refinamientos de la capital, le costó la aceptación social entre los círculos altos de la ciudad de México, que ellos no daban y él no buscaba. En su niñez pasó tres años en la capital del país, donde cursó las primeras letras, pero la muerte de sus padres y el robo de su herencia, de parte de su tutor, lo dejó desamparado. ${ }^{28}$ Hacendado, militar y eventualmente presidente de la República, Álvarez no logró sentirse a gusto lejos de su tierra, ni fue bien recibido. Hombre fuerte del campo que después fue el estado de Guerrero, admirado y temido por los suyos, causó desconfianza y finalmente fue rechazado por la opinión pública del altiplano. No fue exclusivamente el resultado de la discriminación racial o de clase social, sino más bien geográfica. Había un mar de diferencias entre el trato en las zonas rurales de la costa y las grandes urbes (grandes a una escala decimonónica, desde luego). Álvarez, además, sufrió el desprecio de los citadinos por un efecto de contagio, es decir, las tropas que lo acompañaron a la ciudad de México estaban lejos de poseer el refinamiento social de un ejército ideal. El rechazo de la población hacia los recién llegados de la costa incluyó a su caudillo, aunque no tuviera la misma rusticidad que ellos. Estos seguidores del Plan de Ayutla eran considerados "como hordas de salvajes [...] éstos son tan bárbaros y tan brutos como aquéllos [de Atila] y a la vez tan imbéciles y tan degradados como el Negro [Álvarez]". ${ }^{29}$ "Las fuerzas de pintos, faltas de disciplina, cometían actos de barbaridad, tomaron cuarteles en los lugares céntricos de la ciudad y los infestaron al grado de no poder transitar por

${ }^{28}$ Pérez Hernández, Diccionario, p. 345.

${ }^{29}$ Citas varias en Díaz Díaz, Caudillos, p. 288. 
ahí los habitantes de la populosa ciudad, que por falta de policía estaban muy disgustados".$^{30}$ A Álvarez mismo se le menospreciaba por su edad y sus enfermedades, siendo "falta de aptitud por su edad, sus achaques y aun por la misma vida que había llevado". ${ }^{31}$ Anselmo de la Portilla agrega a esta lista su "género de vida" 32 como obstáculo para desempeñar la presidencia, que era una manera de decir que sus costumbres rurales no compaginaban con las exigencias de la vida en Palacio Nacional. Causó una reacción de horror en las clases gobernantes cuando llegó a la ciudad de México para encabezar el gobierno federal, pues se consideraba absurdo "exigir que un individuo posea instrucción y capacidad suficientes para gobernar, cuando ni su educación, ni sus antecedentes, ni sus mismas inclinaciones pueden ponerle en aptitud de satisfacer tal exigencia". ${ }^{33}$ No se salvaba tampoco de los insultos y burlas de la plebe, quien lo "convirtió en el blanco de todo tipo de anécdotas estúpidas y ridículas". ${ }^{34}$ Portilla reseña el fin de su presidencia con estas palabras: "No necesitaba esto el presidente interino para abandonar un puesto que no había ambicionado, y del cual deseaba separarse, para vivir con el sosiego que

30 Rivera Cambas, Los gobernantes de México, vol. v, p. 548. El pinto es una enfermedad muy notoria que cambia el color de la pigmentación de la piel, dejando enormes manchas rosadas en las manos, brazos y cara, causando repugnancia en los que lo observaban.

31 Rivera Cambas, Los gobernantes de México, vol. v, p. 548.

32 Portilla, Historia de la revolución de México, p. 249.

33 El Ómnibus, 291 (5 dic. 1855), p. 3, citado en Díaz Díaz, Caudillos, p. 290.

34 Pérez Hernández, Diccionario, pp. 352 y 353; también citado en Bushnell, La carrera política y militar de Juan Álvarez, p. 243. 
reclamaban su edad y sus modestas costumbres". ${ }^{35}$ No cabe duda de que tenía una clara conciencia de su propio lugar en el mundo: al dejar la rebatinga por el poder dijo: "Pobre entré en la presidencia, y pobre salgo de ella; pero con la satisfacción de que no pesa sobre mí la censura pública, porque dedicado desde mi tierna edad al trabajo personal, sé manejar el arado para sostener a mi familia, sin necesidad de los puestos públicos." 36 La movilidad social que da el dinero no es lo que buscaba. A pesar del alto puesto desempeñado y a pesar de la veneración de la tropa y de los suyos, Juan Álvarez nunca trascendió sus orígenes rurales, no se convirtió en gente de la ciudad ni adoptó los modales de la clase política mexicana. De hecho, nunca dejó de ser militar. Se dice que era un hombre sensible y que le dolió no ser aceptado en los altos círculos sociales, aun después de haber desempeñado la más elevada investidura del país.

Hay más ejemplos de militares que sobresalieron por ejercer con éxito la carrera de las armas, aunque hayan terminado ante un pelotón de fusilamiento. Tomás Mejía es uno de ellos. Indio otomite, nació en 1820 en el muy aislado Pinal de Amoles, de la Sierra Gorda de Querétaro. Aprendió las primeras letras en una escuela de segundo orden en Jalpan, "de la cual salió sin presentar examen para dedicarse luego a las rudas labores del campo". 37 Al poco tiempo pudo enlistarse en el ejército, alcanzando el grado de general antes de morir al lado de Maximiliano en 1867. Envuelto en políticas internacionales que no entendía y jurada su lealtad

35 Portilla, Historia de la revolución de México, p. 253.

36 Portilla, Historia de la revolución de México, p. 254. El autor no da la fuente de la cita textual de Juan Álvarez.

${ }^{37}$ FRÍAs, Leyendas, p. 73. 
a un hombre que no estuvo a la altura de la labor regenerativa que supuestamente llevaría a cabo en México, Mejía pagó con su vida el ascender sin saber a dónde iba.

\section{EL COMPADRAZGO ES LO MEJOR}

Los casos anteriores son ejemplos de ascenso gracias a los conocimientos o a la proeza militar que elevaba a los individuos nacidos lejos de los privilegios de la ciudad a puestos de preeminencia. La educación era un medio limitado a unas cuantas personas, bendecidas con la suerte de haber conseguido un protector, haber estudiado con un maestro inspirado o haber sido un autodidacta inteligente, disciplinado y con suerte. Otra manera, igual o más común de lograr mejorar dramáticamente la posición social, fue la especulación o el gran comercio. Por algo se ha llamado a un periodo en la historia del siglo XIX mexicano "la época de los agiotistas”. ${ }^{38}$ La especulación era un arte. Vivir en la ciudad, sobre todo en la capital, facilitaba cultivar amistades que podrían volverse tan íntimas que se emparentaban vía el matrimonio o espiritualmente, vía el compadrazgo. Se requería de la habilidad de fomentar relaciones sociales ventajosas con personajes como Antonio López de Santa Anna, siempre dispuesto a cambiar un contrato para la importación de algodón por apuestas favorables a él en un juego de cartas, por sólo dar un ejemplo. Otros políticos en posiciones de poder manejaban el mismo esquema, de otorgar contratos a allegados, fueran familiares o espirituales. El presidente Anastasio Bustamante encontró la manera de

38 Tenenbaum, México en la época de los agiotistas. 
ayudar a su compadre, el general Manuel Barrera, con jugosos contratos de manufactura de uniformes para el ejército y de servicios municipales en la ciudad de México: recolección de basura, alumbrado y diversiones (el teatro, una plaza de toros que él mismo construyó). La historiadora Lau Jaiven asegura que "Nada parece apuntar a que Manuel padre haya venido de una familia con dinero. No obstante la familia pudo ascender significativamente en la escala social, de simples sastres devinieron en empresarios". ${ }^{39}$ Al comenzar, es seguro que no les sobraban recursos económicos. Español de nacimiento, el general Barrera supo aprovecharse del trabajo de su numerosa familia, dedicarse a múltiples negocios sin tener suficiente dinero para financiarlos todos, $y$ con astucia y golpes de suerte, acumular una fortuna. Pero la fortuna es veleidosa, las autoridades cambian, las influencias se pierden, el prestigio desaparece. El gobierno no pagó a tiempo los uniformes, que de todas maneras eran de pésima calidad; Barrera no pudo mantener a flote sus negocios, se le acumularon las deudas, y los hijos, después de su muerte, sólo quedaron con el recuerdo amargo de tiempos mejores. Las nubes en el horizonte se hicieron más negras a partir de 1844, cuando a Manuel la falta de pagos lo estaba “empujando a la ruina”. Él no pagaba a sus acreedores, no conseguía crédito en ninguna parte, lo presionaban a tal grado que tuvo que pasar su contrata a un licenciado para cobrar lo que el gobierno le debía, y tal vez debido a la presión, murió al mes. ${ }^{40}$ Lau Jaiven encontró en el archivo

\footnotetext{
39 LaU Jaiven, Las contratas, p. 44 y n. 32.

40 Lau JaIven, Las contratas, p. 105.
} 
militar esta cita de su hijo respecto al final de los cuantiosos bienes de este especulador:

Los desgraciados herederos del general don Manuel Barrera, sólo hubieron por legítima unos cuantos muebles de poco valor, alguna que otra finca incapaz de venderse por falta de compradores, como la de San Agustín de las Cuevas, y créditos contra el gobierno, que he vendido a un cinco por ciento de pago para cubrir mis grandes necesidades, que es lo que vino a reducir la fortuna que con tantos años de trabajo había adquirido". ${ }^{41}$

Una movilidad social espectacular terminó en penosa regresión.

Mientras duraron las concesiones, tanto del Ayuntamiento como del Ministerio de Guerra, el general compró casas y joyas. Una impactante y muy conocida descripción hecha por Fanny Calderón de la Barca de las joyas que llevaba la esposa de Barrera dice:

La señora de Barrera, esposa de un general sumamente rico, y que tiene la casa más hermosa de México [se había comprado la espléndida casa del Marqués del Apartado, José Francisco Fagoaga y Arozqueta, en la calle del Relox $],{ }^{42}$ [... posee aretes de brillantes de un tamaño extraordinario. Un collar de brillantes de inmenso valor, bellamente engarzados, un collar de perlas calabazos, valuado en 20000 pesos. Un brillante sevigné. Una cadena de oro que le daba tres vueltas al cuello y que le

41 Lau Jaiven, Las contratas, p. 233, n. 52.

42 Lau Jaiven, Las contratas, p. 44. 
llegaba a las rodillas. En cada dedo un anillo de brillantes, del tamaño de pequeños relojes. ${ }^{43}$

Nada más que las joyas eran de él, no de ella, y se fueron todas para saldar sus deudas, terminados los días de gloria y presunción. La segunda esposa, una muchacha que se había casado con el general a los 17 años de edad, sin haber tenido tiempo de aprender ni siquiera a leer y escribir, aportó al matrimonio 2000 pesos, así que no era pobre. Manuel le había dado 10000 pesos de arras, 10\% de su caudal, pero la riqueza pasajera no la heredó a la siguiente generación. ${ }^{44}$ Las alianzas matrimoniales ofrecían la posibilidad de un ascenso social o económico, tanto para el hombre como para la mujer, sin que hayan logrado siempre su objetivo, debido a, como en otros tantos casos, la inestabilidad de México en sus tormentosos años de conformación como nación y como sociedad.

\section{DE LEYES, CAUSAS JUDICIALES Y PLEITOS SIN FIN}

Las oportunidades de movilidad social se dieron dentro de una profesión que ganó preeminencia a lo largo del siglo xIx: la abogacía. Dos ejemplos que provienen de la segunda mitad son los del oaxaqueño Rosendo Pineda ${ }^{45}$ y el tabasqueño Joaquín D. Casasús. Según De Maria y Campos, ambos letrados "tuvieron un origen familiar sumamente

43 Calderón de la Barca, La vida en México, carta del 16 de marzo de 1840; también citado en LAU JaIVEN, Las contratas, p. 45.

44 LAU JaIven, Las contratas, pp. 46-47.

45 De Maria y Campos, "Porfirianos prominentes”, pp. 610-661. 
modesto". Dijeron de Casasús, hombre de letras, político, del grupo de los Científicos, que

[...] su niñez no se había mecido en cunas de oro y de marfil, ni era de plata la cuchara que primero se le había acercado a la boca. Hijo de familia pobrísima, su hermano tuvo que trabajar para sostener los estudios...su tío, D. Luis Méndez, lo recibió [en la ciudad de México] como si hubiera sido un parásito que pretendiera un asiento a su mesa. ${ }^{46}$

"En las escasísimas noticias biográficas que se tienen sobre la infancia de Casasús, se alude repetidamente a la falta de recursos familiares", aunque pueda ser una percepción sesgada de parte del personaje, o una distorsión por convenirle a sus intereses personales. Según De Maria y Campos, “muy probablemente [...] el origen de esta versión provenga del propio Casasús, que mucho presumió posteriormente, cuando ya era rico, de su infancia y juventud pobres". ${ }^{47}$ Sin duda lo hacía para resaltar sus propios logros, halagar su vanidad y presentarse ante sus congéneres como un ejemplo a seguir en una sociedad moderna, como supuestamente lo era la porfirista, progresista y avanzada, donde el mérito recibía su justa recompensa. A pesar de sus orígenes, fueran o no muy humildes, "se convirtió en un hombre de gran fortuna por medio de su actividad profesional como abogado y asesor en materia económica". ${ }^{48}$

Rosendo Pineda, hijo natural de un ingeniero francés y una zapoteca, que sola sacó adelante a su hijo con la cría

\footnotetext{
46 Salado Álvarez, Memorias, p. 333.

47 De Maria y Campos, "Porfirianos prominentes", pp. 612-618.

48 De Maria y Campos, "Porfirianos prominentes”, p. 612.
} 
de añil de exportación y como lavandera y planchadora, no hizo una fortuna tan cuantiosa como la de Casasús. ${ }^{49}$ Sin embargo, es otro caso en el cual se puede apuntar a las oportunidades educativas como la puerta de entrada a una vida nueva, una existencia distinta a la llevada por la mayoría de sus compañeros de generación y de lugar y circunstancias de nacimiento. Pineda disfrutó de una beca otorgada por Porfirio Díaz a algunos juchitecos en agradecimiento a su apoyo durante la guerra de Intervención. Al terminar su carrera de abogado en el Instituto Literario de Oaxaca, le dio las gracias a su benefactor firmando como "un criollo pobre", aunque de hecho no era criollo. ${ }^{50}$

\section{UN CASO EXTRAORDINARIO}

No hay otra manera de describir a Juana Catarina Romero. ${ }^{51}$ Tehuana, descalza, analfabeta, huérfana, hija ilegítima, tenía todo en su contra, o dicho de otra manera, todo a favor de llevar una vida marginada, pobre y breve. A los 21 años de edad vendía cigarros a los soldados de ambos bandos de la guerra de Reforma, jugaba a las cartas y a los dados con ellos y al billar. En poco tiempo, en un ascenso extraordinario incluso para un hombre, se convirtió en empresaria importadora de textiles, productora de azúcar, innovadora de técnicas agrícolas, promotora de ferrocarriles y representante en Tehuantepec del Banco Nacional de México. Cuando falleció, a los 77 años de edad, fue la benefactora más importante de la región;

\footnotetext{
49 De Maria y Campos, “Porfirianos prominentes”, p. 613.

50 De Maria y Campos, "Porfirianos prominentes", p. 617.

51 Toda la información acerca de Juana Catarina proviene del excelente artículo de Chassen-López, “A Patron of Progress”, pp. 393-426.
} 
había remozado la catedral, becado a innumerables estudiantes, urbanizado su ciudad natal e influido de manera definitiva en la moda, en la política e incluso en la jerarquía religiosa. ¿Cómo lo logró? Los mitos acerca de su personalidad y sus relaciones con políticos y militares importantes, especialmente Porfirio Díaz, llenan libros. La investigadora Chassen-López ha comprobado que son falsos, que Juana Cata, como se la conoció, logró su posición de gran dama de Tehuantepec a fuerza de trabajo, visión empresarial, extraordinaria inteligencia y sensibilidad. De madre española y padre desconocido, aunque tal vez indígena, se le conoció como indígena, sinónimo de pobre. Su transformación en dama bien vestida a la moda, culta, letrada, empresaria, viajera internacional y benefactora de su pueblo desmiente todas las teorías acerca de la imposibilidad de lograr la movilidad social dentro de una sola generación. Juana está a la par de Benito Juárez, en términos de lo humilde de sus orígenes, de la falta de apoyo familiar, de la distancia entre el pronóstico o la expectativa al nacer y sus logros.

Un aspecto de su historia que vale la pena subrayar es el hecho de que Juana misma consideraba que había superado su condición primitiva de marginada. Cuando escribió al arzobispo Eulogio Gillow, solicitando el nombramiento de párroco para un presbítero amigo suyo, se refería a sí misma como digno objeto de atenciones especiales. Sus viajes de negocios le llevaban con frecuencia a la capital de Oaxaca, donde se hospedaba en casa de los familiares de dicho presbítero, "puesto que me trataban con todas las consideraciones que se merece una señora” ${ }^{52}$

${ }^{52}$ Carta de Juana C. Romero al arzobispo Eulogio Gillow solicitando 
La otra cara de la moneda, el caer en la desgracia, fue una experiencia común en el siglo xix. No hay manera de saber si hubo más gente que cayera en la pobreza de la que saliera de ella, pero como el siglo se caracterizó por una gran miseria para la mayoría y poco avance en la creación de riqueza aun para los más privilegiados, es muy posible que el aumento de los pobres ganara sobre el de los ricos. Concepción Lombardo, una niña que vivió rodeada de los mimos que podía proporcionar un rico comerciante y secretario de Hacienda, aunque fuera por periodos cortos (su padre, Francisco María Lombardo, desempeñó el puesto del 2 al 31 de diciembre de 1834; del 18 de mayo al 26 de julio de 1839; del 23 al 24 de septiembre de 1846; del 8 al 16 de septiembre de 1847), y cuya madre era una de las mujeres más bellas de la época, descendiente de la nobleza española, de repente se vio forzada a cambiar de residencia, a vivir fuera del centro de la ciudad (que significaba no dejarse ver en el teatro, en las tertulias ni en las iglesias de moda, como la Profesa) y a recortar su vida social. Después de morir su padre, el comprobante de depósito de una fuerte suma de dinero en el Banco de Londres, que permitiría a Conchita y a sus dos hermanas vivir desahogadamente, nunca apareció. Los allegados de la familia aconsejaron a las huérfanas no disminuir sus gastos, pues se haría público su desamparo. " $\mathrm{Si}$ ustedes se mudan, nos decían, si quitan el coche y reducen el número de las personas de servicio, nadie las vuelve a ver,

una parroquia para el presbítero d. Felícitos Hernández, 11 de marzo de 1907, en EsParza, Eulogio Gillow y el poder, p. 122. 
y luego se casarán mal". ${ }^{53}$ Las hermanas no hicieron caso de este consejo, economizaron gastos, y Conchita sí pudo casarse con el futuro general y presidente Miguel Miramón. Finalmente no le fue tan bien en la vida, pues el fusilamiento de su marido significó el exilio, años de soledad y penuria.

Algunas casas comerciales, como la de los Martínez del Río y la Casa Barrón y Forbes, se enfrentaron a la bancarrota, igual que Manuel Barrera, por la inestabilidad financiera del gobierno y por especulaciones. Fueron quiebras espectaculares, sobre todo cuando dejaron préstamos sin pagar, con repercusiones en fuentes de trabajo e ingresos de los trabajadores. Otro tipo de quiebras fueron más personales. Antonio Haro y Tamariz, proveniente de una poderosa y rica familia poblana, secretario de Hacienda (del 29 de octubre al 6 de diciembre de 1844; del 25 de septiembre al 13 de noviembre de 1846; del 20 de abril al 5 de agosto de 1853), amigo de Antonio López de Santa Anna y de Mariano Riva Palacio, bon vivant y aventurero, perdió sus haciendas, todas sus fuentes de ingresos, su influencia política, el apoyo de su familia y de sus amigos. Había gastado fuertes sumas en los pronunciamientos en los cuales estuvo involucrado, con la confianza de ganar puestos políticos importantes, tal vez incluso la presidencia del país. Sus cálculos fallaron, no ganaron sus adeptos, nunca recuperó lo prestado a deudores tanto del gobierno como del ejército, no pudo pagar las hipotecas impuestas a sus propiedades y se quedó sin ingresos. En la penuria dejó su cuarto de asistencia en México para trasladarse al Colegio de Nobles de los jesuitas en Roma, donde sirvió como criado hasta el final de su

53 Lombardo de Miramón, Memorias, pp. 2, 61-62. 
vida. Seguramente consideró que era la salida más digna que pudo dar a su vida y que si causaba lástima, nadie en México lo vería. Ni sus hermanos se interesaban ya por su suerte. ${ }^{54}$ Su biógrafo, Jan Bazant, especula acerca de la causa de su empobrecimiento: ¿el juego, enfermedad del siglo, o las mujeres? Parecería que no fue ninguno de ellos, sino inversiones fallidas en la industria, en la agricultura y sobre todo en la política. En 1850 Haro y Tamariz todavía tuvo recursos suficientes para hacerle un préstamo de 3000 pesos al Instituto Literario de Toluca, ${ }^{55}$ además de financiar rebeliones y refaccionar a Santa Anna. Al final de su vida, ni 100 pesos le mandaba la familia para sus gastos más precisos. Si los nobles pudieron seguir gozando de cierto renombre social a pesar de perder la fortuna, este político poblano encontró todas las puertas cerradas.

\section{EL BALANCE DE LA FORTUNA}

¿Qué tienen en común las figuras que sufrieron la pérdida de su fortuna? En casi todos los casos (habrá que exceptuar a Haro y Tamariz y a los prestamistas) fue por causas de fuerza mayor: la muerte del jefe de familia, el robo de los bienes, la destrucción de la propiedad. No fue debido a malas inversiones o a los juegos de azar. Conchita Miramón, Guillermo Prieto y Juan Álvarez fueron víctimas del robo de su patrimonio, al quedar desamparados al morir el padre. Esto habla de la inseguridad de los recursos, de la falta de

\footnotetext{
54 Bazant, Antonio Haro y Tamariz, pp. 157-175.

55 Archivo de Mariano Riva Palacio, 25 de enero de 1850, documento núm. 3769, citado en Girón, Ignacio Manuel Altamirano en Toluca, p. 63.
} 
mayorazgos que aseguraran la transmisión de la herencia o de otros mecanismos que hicieran más expedito pasar los ahorros de una generación a la siguiente, con el fin de perpetuar el rango social y el estilo de vida, en una época en que apenas empezaban a existir las instituciones bancarias, sustitutas de los conventos de monjas que desempeñaron la función de resguardar caudales.

¿QUIÉNES SÍ, QUIÉNES NO, Y POR QUÉ?

¿Qué factores influyeron en el destino de hombres y mujeres que subieron o bajaron en la escala social en el México decimonónico, que lograron forjar fortunas y éxitos o desperdiciaron las oportunidades que les otorgaba un nacimiento privilegiado? Los naturales, como las propias habilidades, vicios, intereses, voluntad y disciplina y la geografía de su entorno. Los culturales, como la oportunidad de asistir a la escuela. Los de la suerte, de ganar una batalla, esquivar una bala o curarse de una enfermedad. Los biológicos, como tener padres que apoyaran el desarrollo de sus hijos o escogieran padrinos que facilitaran los negocios de sus ahijados. De vivir en tiempos de paz o de convertir la guerra en oportunidad para lograr ascensos de grado militar o realizar jugosos contratos. De encontrar la veta de plata en una mina aviada, accesible a los medios de transporte, con mano de obra suficiente y socios honrados. De poder llevar a cabo un negocio en tiempo y forma. De encontrar un trabajo decente a la salida de la escuela. De poder formar una familia cuyos miembros fueran sanos, inteligentes, bien relacionados. El catálogo de causas y efectos incluye tantos ejemplos como casos hubo. El entorno influyó, 
como ya se dijo, pero también el ascenso modificó el entorno. La presencia, en una localidad o dentro de una familia, de un individuo que salía de su estatus original para ascender a otro, tenía un efecto de arrastre. Mejoraba el pueblo o la hacienda o la calle donde habitaba; favorecía a los amigos y a la familia. Las estructuras sociales del siglo xIX mexicano no fueron totalmente rígidas. Hubo espacio para cierto movimiento, sobre todo dentro de las ciudades donde vivían los comerciantes, los profesionistas, los burócratas y los militares cuando no estaban en campaña. No obstante, fortuna y estatus no iban necesariamente de la mano, y más de un comerciante enriquecido o militar poderoso nunca tuvo entrada a los salones de las antiguas familias. De haber sido una sociedad polarizada entre los de abajo y los de arriba, México en el siglo xix empezó a desarrollar una clase media. $\mathrm{Y}$ “estos sectores medios, poco espectaculares, contribuyen de manera significativa a conformar lo que caracteriza la economía y sociedad, local o regional, en un momento histórico determinado", ${ }^{56}$ siendo el resultado del mejoramiento de condiciones de vida e incorporación a una cultura "mexicana" ampliamente extendida por todo el país de numerosos grupos antaño condenados a una vida de grandes privaciones. Por otro lado, hubo relevos entre los antiguos poderosos, la nueva burguesía y las clases dirigentes. Es imposible medir qué tanta sustitución se efectuó, cuánta movilidad tuvo lugar, qué tanta gente superó orígenes familiares sumergidos en la pobreza y la ignorancia. Lo único que se puede afirmar es que sucedió y que fueron menos los niños que tuvieron que aprender, como si fuera dogma de

${ }^{56}$ Mentz, Movilidad, p. 11. 
fe, que cada quien nace con una posición y no puede ni debe andar buscando alterar el orden "natural" de la sociedad.

\section{REFERENCIAS}

Altamirano, Ignacio Manuel

Obras completas, vol. v, Textos costumbristas, edición y prólogo de José Joaquín Blanco, México, Secretaría de Educación Pública, 1986.

Obras completas, vol. vi, Poesía, prólogo y notas de Salvador Reyes Nevares, México, Secretaría de Educación Pública, 1986.

Obras completas, vol. XIII, Escritos de literatura y arte 2, selección y notas de José Luis Martínez, México, Secretaría de Educación Pública, 1988.

Andrews, Catherine

Entre la espada y la Constitución. El general Anastasio Bustamante (1780-1853), Ciudad Victoria, Universidad Autónoma de Tamaulipas, H. Congreso del Estado de Tamaulipas, 2008.

BAZANT, Jan

Antonio Haro y Tamariz y sus aventuras políticas, 1811-1869, México, El Colegio de México, 1985.

Bushnell, Clyde Gilbert

La carrera política y militar de Juan Álvarez, México, Miguel Ángel Porrúa, 1985.

Calderón de la Barca, Fanny Erskine

La vida en México durante una residencia de dos años en ese pais, traducción y prólogo de Felipe Teixidor, México, Porrúa, 1987. 
Chassen-López, Francie R.

"A Patron of Progress: Juana Catarina Romero, the Nineteenth-Century Cacica of Tehuantepec", en The Hispanic American Historical Review, 88:3 (ago. 2008), pp. 393-426.

De Maria y Campos, Alfonso

"Porfirianos prominentes: orígenes y años de juventud de ocho integrantes del grupo de los Científicos, 1846-1876", en Historia Mexicana, xxxıv: 4 (136) (abr.-jun. 1985), pp. 610-661.

Díaz Díaz, Fernando

Caudillos y caciques. Antonio López de Santa Anna y Juan Álvarez, México, El Colegio de México, 1972.

Esparza, Manuel

Eulogio Gillow y el poder. La correspondencia privada como fuente de la historia, Oaxaca, Instituto Nacional de Antropología e Historia, 2004.

FowLER, Will

Malcontents, Rebels, and Pronunciados. The Politics of Insurrection in Nineteenth-Century Mexico (introducción y edición de ...), Lincoln y Londres, Universidad de Nebraska, 2012.

Santa Anna, Xalapa, Universidad Veracruzana, 2010.

Frías, Valentín F.

Leyendas y tradiciones queretanas, Querétaro, Patronato de la Universidad Autónoma de Querétaro, Presidencia Municipal de Querétaro, 1999, vol. I.

Girón, Nicole

Ignacio Manuel Altamirano en Toluca, Toluca, Estado de México, Instituto Mexicano de Cultura, 1993.

Huerta-Nava, Raquel

El guerrero del alba. La vida de Vicente Guerrero, México, Grijalbo, 2007. 
Krauze, Enrique

Siglo de caudillos. Biografía política de México (1810-1910), México, Tusquets Editores, 1995.

LADD, Doris

La nobleza mexicana en la época de la Independencia, 17801826, México, Fondo de Cultura Económica, 1984.

Lau Jaiven, Ana

Las contratas en la ciudad de México. Redes sociales y negocios: el caso de Manuel Barrera (1800-1845), México, Instituto de Investigaciones Dr. José María Luis Mora, 2005.

Lombardo de Miramón, Concepción

Memorias de... Preliminar y algunas notas de Felipe Teixidor, México, Jus, 1994.

Mentz, Brígida von (coord.)

Movilidad social de sectores medios en México: una retrospectiva histórica, siglos XVII al XX, México, Centro de Investigaciones y Estudios Superiores en Antropología Social, Miguel Ángel Porrúa, 2003.

Pérez Hernández, José María

Diccionario geográfico estadístico, histórico, biográfico, de industria y comercio de la República Mexicana escrito en parte $y$ arreglado en otra por el... consultando sus tareas con los distinguidos escritores licenciados Manuel Orozco y Berra y don Alfredo Chavero, t. I, México, Imprenta del Cinco de Mayo, 1874.

Pérez Martínez, Herón

Refranero mexicano, México, Academia Mexicana de la Lengua, Fondo de Cultura Económica, 2004.

Portilla, Anselmo de la

Historia de la revolución de México contra la dictadura del general Santa-Anna 1853-1855, México, Biblioteca de México, 
Fundación Miguel Alemán, Fondo de Cultura Económica, 1993.

Prieto, Guillermo (Fidel)

Memorias de mis tiempos, México, Patria, 1958.

Rivera Cambas, Manuel

Los gobernantes de México, vol. v (1844-1860), obra prologada y continuada por Leonardo Pasquel, México, Citlaltépetl, 1962.

Rodríguez Álvarez, María de los Ángeles

Yo, Gregorio Torres Quintero, Colima, Archivo Histórico del Municipio de Colima, 2014.

Salado Álvarez, Victoriano

Memorias de ... vol. 1. Tiempo viejo, México, Ediapsa, 1946.

Staples, Anne

"El temor a Dios y el temor al Estado: diez lecciones bien aprendidas de la niñez mexicana decimonónica”, en Óscar Mazín (ed.), Las representaciones del poder en las sociedades hispánicas, México, El Colegio de México, 2012, pp. 461-480.

Tenenbaum, Barbara

México en la época de los agiotistas, 1821-1857, México, Fondo de Cultura Económica, 1985.

Valadés, José C.

Obras... don Melchor Ocampo, reformador de México, prólogo y advertencia a la presente edición por Ernesto de la Torre Villar, México, Siglo Veintiuno Editores, 1992.

ZÁrate, Verónica

Los nobles mexicanos ante la muerte en México. Actitudes, ceremonias y memoria (1750-1850), México, El Colegio de México, 2000. 